ARTICLE

\title{
Assessing the Impacts of Climate Change on Crop Yields in Different Agro-climatic Zones of India
}

\author{
Naveen PSingh $^{1^{*}} \quad$ Bhawna Anand $^{1} \quad$ S K Srivastava $^{1} \quad$ KV Rao $^{2} \quad$ S K Bal $^{2} \quad$ M Prabhakar $^{2}$ \\ 1. ICAR-National Institute of Agricultural Economics \& Policy Research (NIAP), New Delhi, India \\ 2. ICAR-Central Research Institute for Dryland Agriculture (CRIDA), Hyderabad, India
}

\begin{tabular}{l}
\hline ARTICLE INFO \\
\hline Article history \\
Received: 10 August 2020 \\
Accepted: 27 August 2020 \\
Published Online: 30 September 2020
\end{tabular}

Keywords:

Agro-climatic zones

Climate change

Crop yields

RCPs

\begin{abstract}
The study attempts to estimate and predict climate impact on crop yields using future temperature projections under two climate emissions scenarios of RCP 4.5 and 8.5 for three different time periods (2030s, 2050s and 2080s) across Agro-climatic zones (ACZ) of India. During the period 1966-2011, a significant rise was observed in both the annual mean maximum and minimum temperature across ACZs. Rainfall recorded an annual decline in Himalayan Regions and Gangetic Plains and a rise in Coastal Regions, Plateau \& Hills and Western Dry Region. Our results showed high heterogeneity in climate impact on kharif and rabi crop yields (with both negative and positive estimates) across ACZs. It was found that rainfall had a positive effect on most of crop yields, but was not sufficient enough to counterbalance the impact of temperature. Changes in crop yield were more pronounced for higher emission scenario of RCP 8.5. Thus, it was evident that the relative impacts of climate change and the associated vulnerability vary by ACZs, hence comprehensive crop and region-specific adaptation measures should be emphasized that helps in enhancing resilience of agricultural system in short to medium term.
\end{abstract}

\section{Introduction}

$\mathrm{C}$ limate change has emerged as the most potent global risk to the food security and agriculture-based livelihoods, impeding the pathway to sustainable development especially among the developing nations. The Intergovernmental Panel on Climate Change ${ }^{[1]}$, states that greenhouse gas accumulation due to increased anthropogenic emissions has caused $1.0^{\circ} \mathrm{C}$ of global warming above the pre-industrial levels which is likely to reach $1.5^{\circ} \mathrm{C}$ between 2030 and 2052. Over the past years for different plausible scenarios, researches have well established the sensitivity of agriculture sector to the changing climatic conditions with concomitant implications for food security ${ }^{[2-5]}$. Agriculture production and productivity are directly influenced by changes in rainfalland temperature ${ }^{[6-9]}$. Temperature when exceed the critical physiological threshold adversely affects crop yield via increased heat stress on crops, water loss by evaporation and proliferation of weeds and pest ${ }^{[10]}$. Also greater erraticism in the distribution of rainfall resulting in drought or flood like situations induces crop failures through higher runoff, soil erosion and loss of nutrients. However, the magnitude of climate impact on agricultural production varies geographically based on agro-ecological zone, technological and socio-economic conditions

*Corresponding Author:

Naveen P Singh,

ICAR-National Institute of Agricultural Economics \& Policy Research (NIAP), New Delhi, India;

Email:naveenpsingh@gmail.com 
${ }^{[11]}$. Besides, location specific adaptation strategies and measures are adopted by the farmers premised on their economic and institutional capacity which are expected to shape the severity of climate impact. Such spatial disparities result in differential climate impact and projections for different crops, for instance, a $2^{\circ} \mathrm{C}$ local warming in the mid-latitudes could increase wheat production by nearly 10 percent ${ }^{[12]}$, whereas in low latitudes the same amount of warming may decrease yields by nearly the same amount. Though the impact of climate change on crop yields could be either positive ornegative; nevertheless, the past evidences generally postulate a negative effect of warming on crop production ${ }^{[13]}$.

India, located close to the equator and in the tropics is disproportionately at a higher risk to the climatic aberrations. The country has diverse geographical and agro-climatic conditions which translate into differential regional impacts. Over the past decades acontinuous rising trend has been observed in both minimum and maximum temperature in the country ${ }^{[14,15,16,17]}$. Though for rainfall there are no clear long-term evidences of variations at the national level ${ }^{[18,19]}$ but regional analysis reveals a changing pattern of precipitation ${ }^{[20,21]}$. This poses enormous challenges for both food production and livelihoods of small-scale farmers' who are already hapless with limited financial resources and access to infrastructure to invest in appropriate adaptation measures ${ }^{[2,23]}$.

In India, several studies have been undertaken to quantify the impact of climate change on crop yields. For instance, the reduction in major crop yields by 4.5 to 9 percent over the period 2010-2039 and by 25 percent in the long-run (2070-2099) without any long-run adaptations was predicted ${ }^{[24]}$. In another study projected that climate change will reduce wheat yield in the range of 6 to 23 percent by 2050 and 15 to 25 percent by $2080^{[25]}$. Also rice yield will be lower by 15 percent and wheat yield by 22 percent towards end of the century ${ }^{[26]}$. By 2080- 2100 there is a probability of 10-40 percent crop loss in the country due to global warming ${ }^{[7]}$. Further, high losses in crop yield ranging from 30 to 40 percent have been projected by 2080 , both with and without carbon fertilization ${ }^{[27]}$. By end of this century,the productivity of cereal crops like rice and wheat will be negatively impacted for $2-4^{\circ} \mathrm{C}$ increase in temperature and rise in the rate of precipitation $^{[28]}$. Moreover, yields of wheat, soybean, mustard, groundnut and potato are expected to decline by 3-7percent for $10 \mathrm{C}$ rise in temperature ${ }^{[29]}$. Most of the previous assessments have extrapolated climate impact on crop yields at a national and state level; however, there remains a considerable uncertainty over the likely climate impact for homologous environments. Hence, there is a dire need to get empirics related to the impact of climate change for major crops at agro-climatic zone level so that location specific R\&D and dynamic, diversified and flexible interventions having local contexts can be suggested ${ }^{[30,31]}$. Thus, the present study examined the impact of climate variables on major kharif and rabi crop yields, across agro-climatic zones (ACZs) delineated by the erstwhile Planning Commission, Government of India ${ }^{[32]}$ for the period 1966 to 2011. Further, the study projected the likely changes in crop yields for different time periods across the zones.

\section{Agro-climatic Zones: Spread and Charac- teristics}

Regional heterogeneity across the Indian geographical landscape significantly influence the growth and development of agriculture system, leading to existence of inter/intra-regional disparities in rural income and technology adoptions ${ }^{[33]}$. In the course of changing climatic conditions and depletion of natural resources base, sustainability of agriculture necessitates development of effective technologies and differentiated mechanisms that address region-specific farm-level issues. This requires constructing spatially disaggregated plans for homogeneous regions that bring synergy between the core components of technology for resource-use efficiency. The genesis of regionalization of national agriculture economy by Planning Commission goes back to 1989 wherein the mainland of India was retrenched into 15 agro-climatic zones based on physical conditions, topography, soil, geological formation, rainfall pattern, cropping system, development of irrigation and mineral resources ${ }^{[34]}$. The regionalization exercise was undertaken with the prime objective of internalizing the resource development potentials and physical distinction across states/ regions in the country into the developmental policy and programme formulation and implementation ${ }^{[35]}$. Table 1, depicts the spatial characteristic of 14 agro-climatic zones (excluding the island region), wherein it was found that Southern Plateau \& Hills (comprising parts of Andhra Pradesh, Karnataka and Tamil Nadu) and Eastern Plateau \& Hills occupied the largest geographical area. Middle Gangetic Plains comprising Bihar and parts of Uttar Pradesh was the most populated, while Western Himalayan Region had the lowest population. Western Plateau \& Hills had the largest net sown area of about 19.66 million hectares. This was followed by Southern Plateau \& Hills and Central Plateau \& Hills with a net sown area of approximately 18.08 and 16.78 million hectares, respectively. In case of food grain productivi- 


\begin{tabular}{|c|c|c|c|c|c|c|c|c|c|c|c|c|c|c|c|}
\hline & 总 & 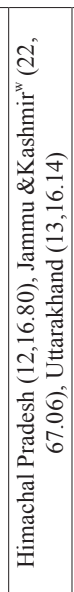 & 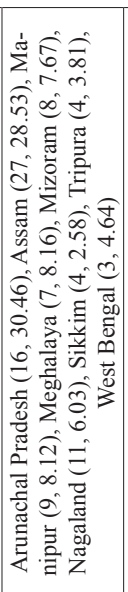 & 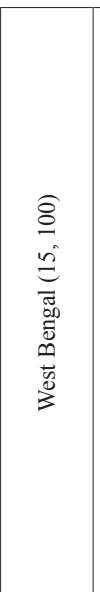 & 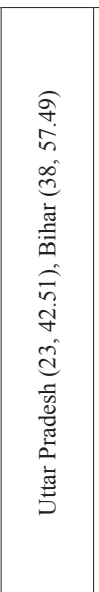 & 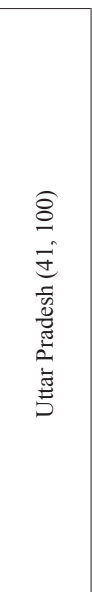 & 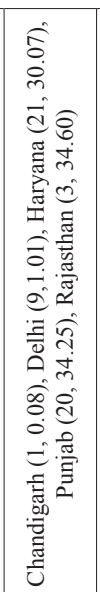 & 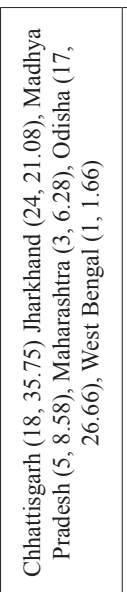 & 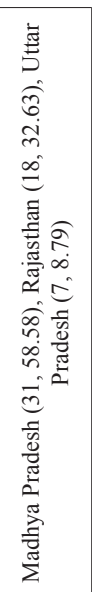 & 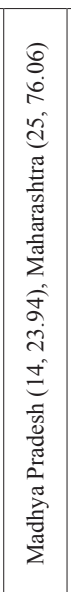 & 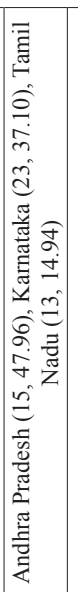 & 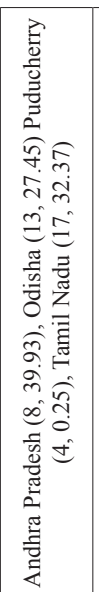 & 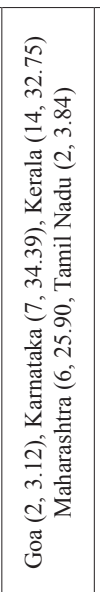 & 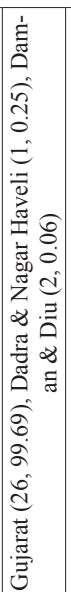 & 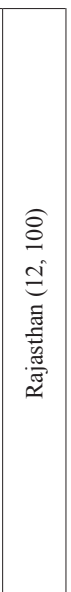 \\
\hline & 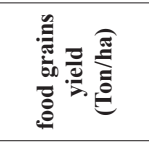 & $\stackrel{\infty}{\stackrel{\infty}{i}}$ & 赵 & $\begin{array}{l}\hat{b} \\
\text { ì }\end{array}$ & ్ㅐㅁ & 柋 & 导 & : & 守 & $\begin{array}{l}\vec{b} \\
\stackrel{2}{n}\end{array}$ & त̂ & $\begin{array}{l}\stackrel{0}{0} \\
\stackrel{0}{i}\end{array}$ & 龸 & 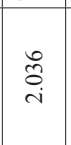 & $\begin{array}{l}\text { کू } \\
\stackrel{-}{2}\end{array}$ \\
\hline $\begin{array}{l}: \frac{\pi}{\tilde{g}} \\
\Xi\end{array}$ & 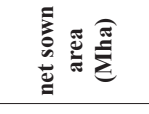 & $\stackrel{\text { aे }}{-}$ & $\begin{array}{l}\stackrel{0}{\sigma} \\
\dot{+}\end{array}$ & 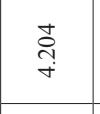 & 总 & 各 & 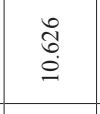 & $\vec{\sigma}$ & 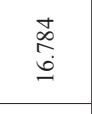 & $\begin{array}{l}\stackrel{0}{0} \\
\stackrel{\square}{-}\end{array}$ & $\begin{array}{l}\tilde{\alpha} \\
\stackrel{\infty}{\infty}\end{array}$ & 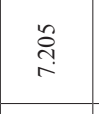 & ণे ఫे & হूă & $\begin{array}{l}\hat{A} \\
\text { à }\end{array}$ \\
\hline $\begin{array}{l}. \Xi \\
\sim \\
0 \\
\tilde{0} \\
N \\
. \\
.\end{array}$ &  & 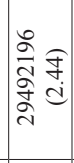 & 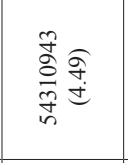 &  & 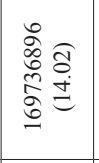 & 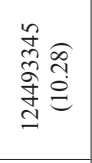 & 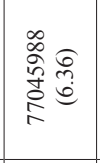 & 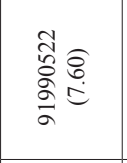 & 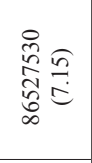 & 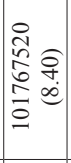 & 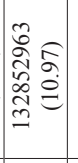 & 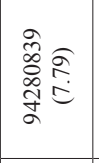 & 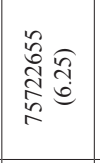 & 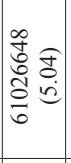 & 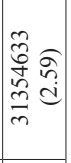 \\
\hline 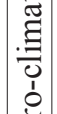 & & 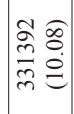 & 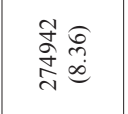 & 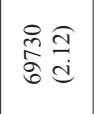 & 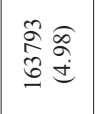 & 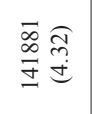 & 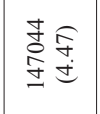 & 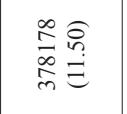 & 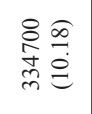 & 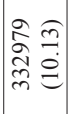 & 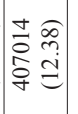 & 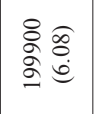 & 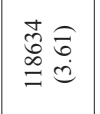 & 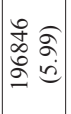 & 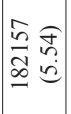 \\
\hline 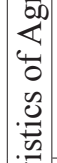 & 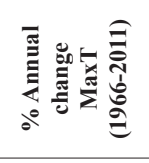 & $\begin{array}{l}* \\
\text { * } \\
\text { कo } \\
\vdots \\
0 \\
0\end{array}$ & 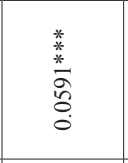 & 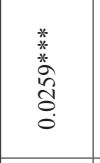 & 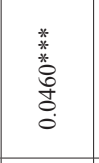 & 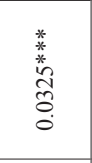 & $\begin{array}{l}\text { *. } \\
\text { * } \\
0 \\
\infty \\
0 \\
0 \\
0\end{array}$ &  & $\begin{array}{l}\text { 券 } \\
\text { 总 } \\
\text { o. } \\
0\end{array}$ & 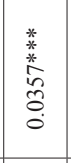 & 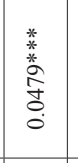 &  & 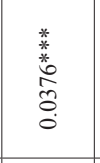 & 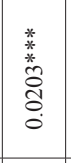 & 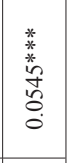 \\
\hline 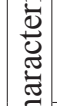 & 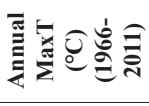 & $\begin{array}{l}\hat{A} \\
\text { ते } \\
\end{array}$ & $\begin{array}{l}\stackrel{\infty}{\triangle} \\
\stackrel{\sim}{\sim}\end{array}$ & 兮 & 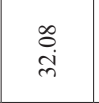 & 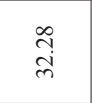 & 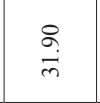 & $\frac{\text { f }}{\dot{m}}$ & 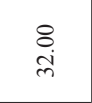 & $\begin{array}{l}\vec{\sigma} \\
\vec{j} \\
\vec{m}\end{array}$ & $\begin{array}{l}\text { तె } \\
\text { } \\
\text { - }\end{array}$ & $\stackrel{+}{m}$ & 灾 & $\begin{array}{l}\vec{i} \\
\text { m }\end{array}$ & 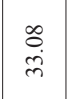 \\
\hline $\begin{array}{l}\bar{U} \\
\dot{\vec{d}}\end{array}$ & 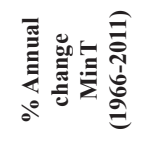 & 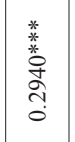 & $\begin{array}{l}\frac{*}{*} \\
\stackrel{*}{*} \\
\stackrel{\tilde{n}}{0} \\
0\end{array}$ & $\begin{array}{l}\frac{*}{*} \\
\stackrel{*}{6} \\
0 \\
0\end{array}$ & 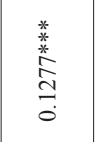 & 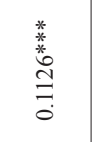 & 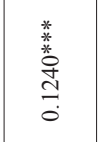 & 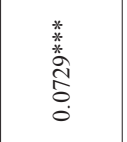 & $\begin{array}{l}\text { 蒡 } \\
\text { 岁 } \\
0 \\
0\end{array}$ & 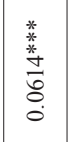 & 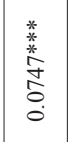 & $\begin{array}{l}\text { *. } \\
\text { *3. } \\
0 \\
0 \\
0 \\
0\end{array}$ & $\begin{array}{l}\text { 絭 } \\
\text { 妾 } \\
0 \\
0 \\
0 \\
0\end{array}$ & \begin{tabular}{|l|}
$*$ \\
* \\
*a \\
0 \\
0 \\
0 \\
\end{tabular} & 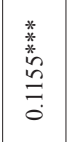 \\
\hline & 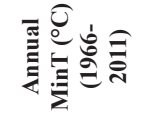 & $\stackrel{\infty}{\underset{ \pm}{ \pm}}$ & 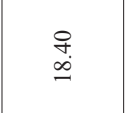 & $\stackrel{\overrightarrow{4}}{\overline{4}}$ & $\stackrel{\text { ra }}{g}$ & $\begin{array}{l}\infty \\
\infty \\
\infty \\
\stackrel{\infty}{0}\end{array}$ &  & $\stackrel{n}{\sigma}$ & $\stackrel{m}{a}$ & $\begin{array}{l}\stackrel{n}{\sigma} \\
\stackrel{g}{\sigma}\end{array}$ & $\underset{\vec{\sim}}{\vec{\sim}}$ & $\stackrel{\infty}{\underset{j}{\lambda}}$ & $\begin{array}{l}: \\
\stackrel{\text { ते }}{ }\end{array}$ & $\stackrel{n}{\sigma}$ & $\begin{array}{l}\stackrel{r}{a} \\
\stackrel{\infty}{\rightarrow}\end{array}$ \\
\hline &  & 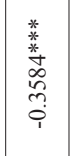 & 䓂 & $\begin{array}{l}\text { oे } \\
\text { के } \\
\text { iे }\end{array}$ & $\frac{m}{\vec{T}}$ &  & $\begin{array}{l}\text { હे } \\
\hat{0} \\
\stackrel{i}{1}\end{array}$ & $\begin{array}{l}\text { *ैं } \\
\stackrel{*}{0} \\
0 \\
0\end{array}$ & 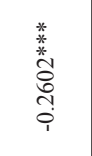 & $\begin{array}{l}\tilde{0} \\
0 \\
0 \\
0\end{array}$ & 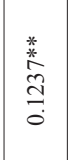 & $\begin{array}{l}\stackrel{*}{c} \\
\stackrel{m}{0} \\
\stackrel{0}{0}\end{array}$ & $\begin{array}{l}\tilde{0} \\
\stackrel{0}{0} \\
0 \\
0\end{array}$ & 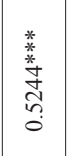 & 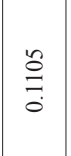 \\
\hline & 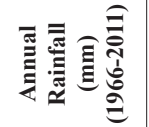 & $\begin{array}{l}\overrightarrow{\vec{\gamma}} \\
\stackrel{\infty}{n} \\
\stackrel{n}{=}\end{array}$ & 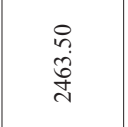 & 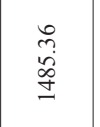 & $\begin{array}{l}\stackrel{ \pm}{\oplus} \\
\stackrel{\Xi}{\Xi}\end{array}$ &  & 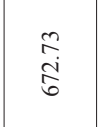 & 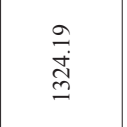 & $\begin{array}{l}\stackrel{8}{\stackrel{0}{0}} \\
\stackrel{\leftrightarrow}{\sigma}\end{array}$ & $\begin{array}{l}\text { ڤ̆ } \\
\text { aें }\end{array}$ & 声 & $\begin{array}{l}\stackrel{\circ}{\circ} \\
\stackrel{\circ}{=}\end{array}$ & 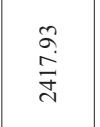 & 点 & 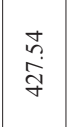 \\
\hline & 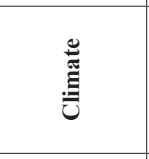 & 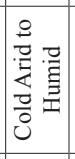 & 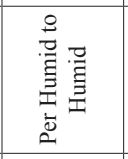 & 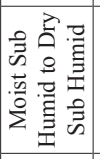 & 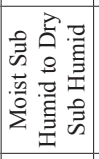 & 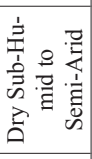 & 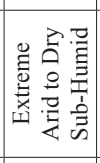 & 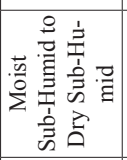 & 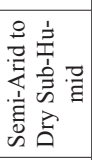 & 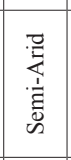 & : & 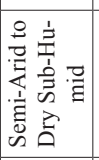 & 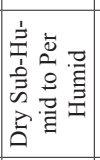 & 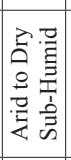 & 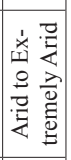 \\
\hline & 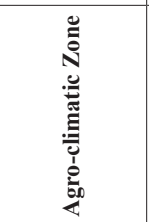 & 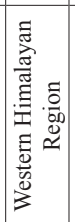 & 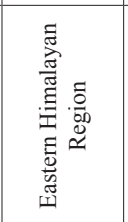 & 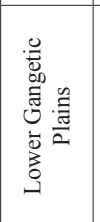 & 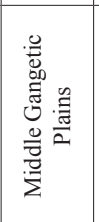 & 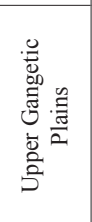 &  & 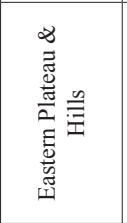 & 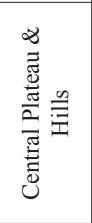 & 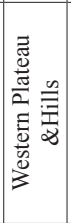 & 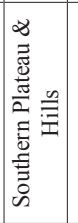 & 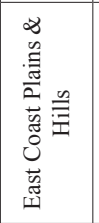 & 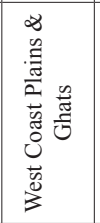 & 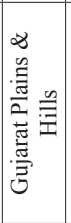 & 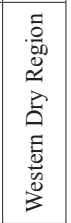 \\
\hline
\end{tabular}

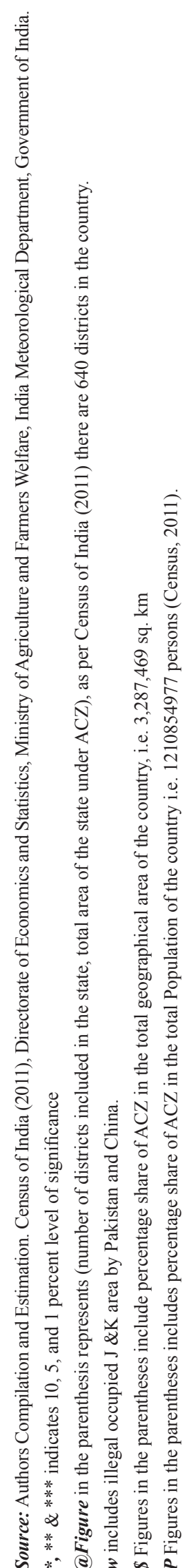


ty, Trans-Gangetic Plains recorded the highest average foodgrain yield of 3.60 tones/ hectare.

Wide variations were observed in the distribution of rainfall across the zones. During the period 1966-2011, Eastern Himalayan Region (comprising north-eastern states and parts of West Bengal) followed by West Coast Plains \& Ghats, have received the highest amount of annual rainfall whereas Western Dry Region and Trans-Gangetic Plains have received the lowest rainfall. Further, while rainfall registered an annual decline in the Himalayan regions and Gangetic Plains, it increased in Western and Southern Plateau \& Hills and Coastal regions. The annual mean minimum temperature was the lowest in Western Himalayan Region comprising high altitude states of Himachal Pradesh, Jammu \& Kashmir and Uttarakhand. On the other hand, East Coast Plains \& Hills, Southern Plateau \& Hills and Lower Gangetic Plains recorded the highest annual mean minimum temperature among the ACZs. Western Dry Region and Western Plateau \& Hills had the highest mean maximum temperature. The estimates showed an increase in both the annual mean maximum and minimum temperature in all the ACZs with more pronounced changes in the minimum temperature. The increase in maximum temperature was significantly higher in Himalayan regions followed by Western Dry Region (parts of Rajasthan) and Central Plateau \& Hills. On the other spectrum, the rate of increase in the minimum temperature was higher in both the Himalayan Regions followed by the Middle and Trans-Gangetic Plains indicating an accelerated warming during the period.

\section{Data Sources}

In this paper, a comprehensive district-level panel, on $301{ }^{\oplus}$ districts spread across 14 agro-climatic zones was constructed for the period 1966-2011. The crop yields were paired with climate parameters (temperature and rainfall) and certain control variables to develop this large-scale panel which allows for inter-temporal and spatial assessment whilst controlling for district-specific factors and time trend. The data on area and production of crops and control factors like irrigated area, road length, literacy, tractors, pump sets and fertilizer consumption were compiled from the database maintained by International Crops Research Institute for the Semi-Arid Tropics (ICRISAT) under the Village Dynam-

(1) ICRISAT-VDSA database contains data for 311 districts spread across 19 states of India from 1966-67 to 2011-12 with 1966 base district boundaries. Due to different periodicity and paucity of data on certain variables and to create a balanced panel, a total of 301 districts were finally selected for the study. ics Studies in Asia (VDSA) project. Further, crops that were dominantly grown in the particular agro-climatic zone were purposely selected for assessment. The data on rainfall and temperature (minimum and maximum) were obtained from the India Meteorological Department (IMD), Government of India and later aggregated into the annual district metrics for the entire crop growing period. For the study, crop growing period is taken as a composite of sowing, germination and harvesting months for the respective crop.

\section{Methodology}

\subsection{Method}

There have been continuous methodological improvements for estimating the impact of climate variables (temperatures and rainfall) on agriculture production. Each method has been developed systematically to address some of the limitations of the former. In literature, three approaches have been widely used for analysing the economic effects of climate change on crop productivity: (1) Production function method, (2) Ricardian model, and (3) Panel data approach. Production function method, also known as crop modelling or agronomic-economic model, is a laboratory-type setup wherein under controlled experimental conditions, crops are exposed to a varied degree of climate scenarios and carbon dioxide levels, keeping farm level adaptations constant to study how change in rainfall, temperature and carbon dioxide precisely affect crops ${ }^{[3,37,38,39]}$. The Production function approach, however, does not reflect the farmer's adaptive behaviour to changing climatic conditions and thus it is likely to produce climate estimates that are downward biased ${ }^{[40]}$. In an alternative to crop simulation models, the cross-sectional Ricardian approach ${ }^{[4]]}$, which measures the impact of climate change on the net rent or value of agriculture land while integrating farmers' compensatory responses pertaining to the changes in both crop and input decisions. This method is similar to the hedonic price method of environmental valuation and explains regional differences in land values or productivity due to differences in climatic factors. However, the major lacuna with Ricardian approach is the omitted variable bias ${ }^{[40,24]}$. This can occur if the critical farm variables (soil type, irrigation, and population density) correlated with climate is omitted from the regression model, leading to estimates that are not only biased but also inconsistent in nature. In the recent times, several researchers have used the panel data approach ${ }^{[42,40,24,26]}$ to capture the effects of year-to-year change in climate variables on agriculture output by controlling for time-in- 
variant un-observables (e.g. soil and water quality) that may be correlated with climate and dependent variable, thereby reducing the possibility of an omitted variable bias. Also the spatial fixed effects capture region/ location specific time variant factors that may influence crop productivity ${ }^{[43]}$. Besides, with the panel data it is possible to account for short-term adaptations by the farmers in estimating the climate impact on agriculture productivity. Therefore, we used panel data approach to assess climate impact across different zones.

\subsection{Empirical Specification}

The present study used the following model specification to examine the impact of climate change on crop yields in each of the ACZ,

$\log y_{d t}=c+\alpha_{d}+\partial t+\gamma \log X_{d t}+\beta \log W_{d t}+\varepsilon_{d t}$

where $y_{d t}$ represents crop yield, $W_{d t}$ is a vector of climate variables (rainfall, maximum and minimum temperatures), $X_{d t}$ denotesvector of controlvariables and $\varepsilon_{d t}$ is the error term for the $d^{\text {th }}$ district during the $t^{\text {th }}$ time period, respectively. The model includes district level fixed effects, $a_{d}$ which controls for unobserved district specific heterogeneity due to time-invariant factors that influence dependent variable. In their analysis, authors $[40,24,44]$ all added entity fixed effects to eliminate the omitted variable bias. Further, a time trend has been incorporated in the model, as a proxy to absorb the technological effects and other farm level adaptations within an ACZ.

To ensure robustness of the applied panel regression, certain residual diagnostics were employed. We testedfor the first order autocorrelation in the residuals of a linear panel-data using the Woolridge test ${ }^{[45]}$ of Homoscedasticity of error process across cross-sectional units was investigated through modified Wald test for group-wise heteroscedasticity ${ }^{[46]}$. Interestingly, with the application of the above procedures we found the presence of autocorrelation in most of the cases across the ACZs but there was no incidence of errors exhibiting group-wise heteroscedasticity. The latter may be attributed to the inclusion of trend component which corroborates with the findings of ${ }^{[45]}$ and ${ }^{[45]}$ of how incorporation of common trend in the panel imparts homogeneity across the cross-sectional units. Based on the above verifications, we applied feasible generalized least squares (FGLS) method with corrections for autocorrelation to estimate model (1) under the assumptions that; within panels, there is AR (1) autocorrelation and that the coefficient of the AR (1) process is common to all the panels. Howev- er, it is important to note that FGLSis feasible and tends to produce efficient and consistent estimates of standard errors, provided that $\mathrm{N}<\mathrm{T}$ that is panel time dimension, $\mathrm{T}$, is larger than the cross-sectional dimension, $\mathrm{N}^{[4,50,51]}$. In our case, this assumption was satisfied as under each $\mathrm{ACZ}$, the numbers of districts representing the cross-sectional units $(\mathrm{N})$ were less than the time period.

\subsection{Marginal Effects}

The marginal effects of the climate parameters were calculated at their mean values from the regression coefficients. Under the model specification (1), the regression coefficients measure elasticity, i.e. proportionate change in crop yield to proportionate change in the independent variable. Hence, the combined marginal effect of climate variables, viz. rainfall, minimum and maximum temperature on crop yield was estimated using equation (2).

$\frac{\mathrm{dy}}{\mathrm{dc}}=\left(\beta_{\mathrm{MT}} *\left[\frac{\overline{\mathrm{Y}}}{\overline{\mathrm{MT}}}\right]+\beta_{\mathrm{MNT}} *\left[\frac{\overline{\mathrm{Y}}}{\overline{\mathrm{MNT}}}\right]+\beta_{\mathrm{R}} *\left[\frac{\overline{\mathrm{Y}}}{\overline{\mathrm{R}}}\right]\right)$

Where, $\frac{d y}{d c}$ is combined marginal effect of change in climate variables on the crop yield, $\beta$ denotes coefficients which are determined from the model, $\overline{\mathrm{MT}}$ is mean maximum temperature, $\overline{\mathrm{MNT}}$ is mean minimum temperature, $\overline{\mathrm{R}}$ is mean rainfall, and $\overline{\mathrm{Y}}$ is the mean crop yield during the period in an ACZ.

\subsection{Future Climate Change Projections}

The study used CORDEX South Asia multi-RCM reliability ensemble average estimate of projected changes in annual mean minimum and maximum temperature over India for the 30-year future periods: near-term (20162045), mid-term (2036-2065) and long-term (2066-2095) changes in future climate over India under RCPs 4.5and $8.5^{\mathbb{\Phi}}$ scenarios relative to the base $1976-2005$ to project the changes in crop yields ${ }^{[52]}$. In the near-term period, a similar increase of less than $2^{\circ} \mathrm{Cin}$ the mean minimum and maximum temperature was observed for both RCP4.5 and 8.5(Table 2).

(1) The Representative Concentration Pathways (RCPs) used by IPCC in its Fifth Assessment Report (AR5, 2014) describes the future trend in greenhouse gases concentration in the atmosphere due to human activities. The pathway delineates four future climate scenarios of RCP2.6, RCP4.5, RCP6.0 and RCP8.5, premised on different emission levels, energy use and socio-economic circumstances. For impact assessment we focused on RCPs 4.5 and 8.5 representing moderate and worst-case (business-as-usual) scenario. 
Table 2. Projected changes annual mean minimum and maximum temperature over India

\begin{tabular}{|c|c|c|c|c|}
\hline \multicolumn{5}{|c|}{ Variable } \\
\hline $\begin{array}{c}\text { Minimum } \\
\text { tempera- } \\
\text { ture }\end{array}$ & $\begin{array}{c}\text { Scenari- } \\
\text { os }\end{array}$ & $\begin{array}{c}\text { Near-term } \\
(2030 \mathrm{~s})\end{array}$ & $\begin{array}{c}\text { Mid-term } \\
(2050 \mathrm{~s})\end{array}$ & $\begin{array}{c}\text { Long-term } \\
(2080 \mathrm{~s})\end{array}$ \\
\hline $\begin{array}{c}\text { Max- } \\
\text { imum } \\
\text { tempera- } \\
\text { ture }\end{array}$ & RCP 4.5 & $\begin{array}{c}1.36 \pm 0.18 \\
(13.2 \%)\end{array}$ & $\begin{array}{c}2.14 \pm 0.28 \\
(13.1 \%)\end{array}$ & $\begin{array}{c}2.63 \pm 0.38 \\
(14.4 \%)\end{array}$ \\
\cline { 2 - 5 } & RCP 8.5 & $\begin{array}{c}1.50 \pm 0.16 \\
(10.7 \%)\end{array}$ & $\begin{array}{c}2.60 \pm 0.23 \\
(8.8 \%)\end{array}$ & $\begin{array}{c}4.43 \pm 0.34 \\
(7.7 \%)\end{array}$ \\
\hline & RCP 4.5 & $1.26 \pm 0.20$ & $1.81 \pm 0.27$ & $2.29 \pm 0.36$ \\
& $(15.9 \%)$ & $(14.9 \%)$ & $(15.7 \%)$ \\
\cline { 2 - 5 } & RCP 8.5 & $\begin{array}{c}1.36 \pm 0.16 \\
(11.8 \%)\end{array}$ & $\begin{array}{c}2.30 \pm 0.31 \\
(13.5 \%)\end{array}$ & $\begin{array}{c}3.94 \pm 0.45 \\
(11.4 \%)\end{array}$ \\
\hline
\end{tabular}

Figure in the parenthesis indicate the associated uncertainty range

Source: Climate Change over India: An Interim report (2017). Centre for Climate Change Research, ESSO-IITM, Ministry of Earth Sciences, Govt. of India

The mid-term warming in minimum temperature is projected to be in the range of 2.14 to $2.60^{\circ} \mathrm{C}$ while for the maximum temperature it is around 1.81 to $2.30^{\circ} \mathrm{C}$.Under the RCP 4.5 minimum and maximum temperature surpasses $2^{\circ} \mathrm{C}$ by the end of the 21 st century. In the far future minimum temperature is projected to increase beyond $4^{\circ} \mathrm{C}$ for RCP 8.5 with high degree of certainty. Overall, it is observed that the magnitude of changes in all India annual minimum temperature exceeds the changes estimated for the maximum temperature.

Further, a variation of 5,10 and 12 percent in rainfall was assumed for the period of 2030s, 2050s and 2080sfor under the two scenarios. The direction of rainfall anomaly (positive or negative) for each of the ACZ was based on rainfall trend during the period from 2001-2011. The projected impactof climate change on crop yield expressed as percentage change was calculated using equation (3),

$\Delta Y=\left(\frac{\partial Y}{\partial R}\right) * \Delta R+\left(\frac{\partial Y}{\partial T}\right) * \Delta T * 100$

Where, $\Delta Y$ denotes change in crop yield, $\Delta R$ in rainfall and $\Delta T$ in temperature under and $\left(\frac{\partial \mathrm{Y}}{\partial \mathrm{R}}\right)$ and $\left(\frac{\partial \mathrm{Y}}{\partial \mathrm{T}}\right)$ are their marginal effects estimated from the model.

\section{Results and Discussion}

\subsection{Marginal Effect and Projected Change for kharif Crop Yields}

\subsubsection{Marginal Effects}

During the period from 1966-2011, a decline in rice yield was observed in nearly all the ACZs, with the highest reduction of 2.62 percent found in Eastern Himalayan
Region (covering north-eastern states and parts of West Bengal). As shown in Table 3, maize yield declined in Central Plateau \& Hills Western Dry Region, Trans-Gangetic Plainsand Upper Gangetic Plains by 1.33, 1.03, 0.65 and 0.03 percent, respectively. Regional variations are reflected from the fact that, while maize was negatively impacted by climatic variations in the above regions, it was benefitted in Himalayan Regions, Lower Gangetic Plains and Middle Gangetic Plains. The maximum reduction in groundnut occurred in Southern Plateau \& Hills and West Coast Plains \& Ghats, whereas in Central Plateau $\&$ Hills it showed an increase of 0.55 percent. Sorghum yield showed a decline of 4.54 percent in Central Plateau $\&$ Hills (covering parts of Madhya Pradesh, Rajasthan and Uttar Pradesh) and an increase of 4.68 percent in Western Plateau \& Hills. The yield loss for sugarcane was to the extent of 9.91, 8.02 and 3.66 percent in East Coast Plains \& Hills, Middle Gangetic Plains and Western Plateau \& Hills, respectively. While Pearl millet yield showed an increase of 2.09 percent in Trans-Gangetic Plains, it registered a decline of 1.23 and 0.84 percent in Gujarat Plains $\&$ Hills and Western Dry Region. Finger millet increased by 1.10 percent in West Coast Plains \& Ghats. Further, the effect of climatic variations has been found to be negative for cotton in Western Plateau \& Hills and Trans-Gangetic Plains, where yield reduced by 1.74 and 0.59 percent.

\subsubsection{Projected Impact under RCP 4.5}

The climate projections showed that rice yield will decline by 5.49 and 6.79 percent in Eastern Himalayan Region by 2050 s and 2080s. In near-term it is likely to reduce by 2.94 and 3.56 percent in Western and Eastern Himalayan Region. In case of both Eastern and Southern Plateau $\&$ Hills, rice yield will decline by about 1.7 percent by 2050s, respectively. By 2080s maize is likely to increase by around 7 to 8 percent in Western Himalayan Region and Lower Gangetic Plains. Yield loss in case of groundnut is expected to be around 5 percent by 2050s in Gujarat Plains \& Hills. In near-term, groundnut yield will reduce by 1.96 and 1.82 percent in Southern Plateau \& Hills and West Coast Plains \& Ghats whereas, it will increase by 0.95 percent in Central Plateau \& Hills. In the mid and long-term periods, sorghum is likely to increase around 8 and 11 percent in Western Plateau \& Hills and decrease by the same magnitude in Central Plateau \& Hills respectively. Cotton yieldwill decline the most in Western Plateau \& Hills followed by Trans-Gangetic Plains. For sugarcane, yield is projected to decline by 11 and 13 percent in Middle Gangetic Plains (covering Bihar and parts of Uttar Pradesh) and East Coast Plains \& Hills by 2030s. Pearl millet is likely to increase by 15.58 percent by mid-term 
Table 3. Regionally aggregated climate change impacts and projections for kharif crop yields(percent)

\begin{tabular}{|c|c|c|c|c|c|c|c|c|}
\hline \multirow{5}{*}{$\begin{array}{l}\text { Agro-climatic } \\
\text { Zone }\end{array}$} & \multirow{5}{*}{ Crops } & \multirow{5}{*}{$\begin{array}{l}\text { Marginal } \\
\text { Effects }\end{array}$} & \multicolumn{3}{|c|}{ With RCP 4.5 temperature projections } & \multicolumn{3}{|c|}{ With RCP 8.5 temperature projections } \\
\hline & & & $2030 \mathrm{~s}$ & $2050 \mathrm{~s}$ & $2080 \mathrm{~s}$ & $2030 \mathrm{~s}$ & $2050 \mathrm{~s}$ & $2080 \mathrm{~s}$ \\
\hline & & & $\Delta \mathrm{MinT}=1.36$ & $\Delta \mathrm{MinT}=2.14$ & $\Delta \operatorname{MinT}=2.63$ & $\Delta \mathrm{MinT}=1.50$ & $\Delta \operatorname{Min} T=2.60$ & $\Delta \mathrm{MinT}=4.43$ \\
\hline & & & $\Delta \mathrm{MaxT}=1.26$ & $\Delta \mathrm{MaxT}=1.81$ & $\Delta \mathrm{MaxT}=2.29$ & $\Delta \mathrm{MaxT}=1.36$ & $\Delta \mathrm{MaxT}=2.30$ & $\Delta \mathrm{MaxT}=3.94$ \\
\hline & & & $\Delta \mathrm{R}=(+/-) 5 \%$ & $\begin{array}{c}\Delta \mathrm{R}=(+/-) \\
10 \%\end{array}$ & $\begin{array}{c}\Delta \mathrm{R}=(+/-) \\
12 \%\end{array}$ & $\Delta \mathrm{R}=(+/-) 5 \%$ & $\begin{array}{c}\Delta \mathrm{R}=(+/-) \\
10 \%\end{array}$ & $\Delta \mathrm{R}=(+/-) 12 \%$ \\
\hline \multirow{2}{*}{$\begin{array}{l}\text { Western Hima- } \\
\text { layan Region }\end{array}$} & Rice & -2.34 & -2.94 & -4.41 & -5.49 & -4.02 & -5.52 & -9.59 \\
\hline & Maize & 3.29 & 4.17 & 5.97 & 7.57 & 4.49 & 7.59 & 12.95 \\
\hline \multirow{2}{*}{$\begin{array}{l}\text { Eastern Hima- } \\
\text { layan Region }\end{array}$} & Rice & -2.62 & -3.56 & -5.49 & -6.79 & -3.89 & -6.72 & -11.39 \\
\hline & Maize & 1.33 & 1.83 & 2.97 & 3.61 & 2.04 & 3.56 & 6.10 \\
\hline \multirow{2}{*}{$\begin{array}{c}\text { Lower Gangetic } \\
\text { Plains }\end{array}$} & Rice & -1.17 & -1.60 & -2.34 & -2.96 & -1.71 & -2.92 & -4.87 \\
\hline & Maize & 2.83 & 3.99 & 6.29 & 7.74 & 4.37 & 7.60 & 12.78 \\
\hline \multirow{3}{*}{$\begin{array}{l}\text { Middle Gangetic } \\
\text { Plains }\end{array}$} & Rice & -0.17 & -0.26 & -0.41 & -0.51 & -0.28 & -0.49 & -0.80 \\
\hline & Maize & 0.19 & 0.45 & 0.79 & 0.96 & 0.48 & 0.87 & 1.30 \\
\hline & Sugarcane & -8.02 & -11.15 & -17.43 & -21.50 & -12.21 & -21.17 & -35.70 \\
\hline \multirow{4}{*}{$\begin{array}{l}\text { Upper Gangetic } \\
\text { Plains }\end{array}$} & Rice & -0.07 & -0.16 & -0.27 & -0.33 & -0.17 & -0.30 & -0.45 \\
\hline & Sugarcane & -0.13 & -0.77 & -1.57 & -1.85 & -0.82 & -1.60 & -2.18 \\
\hline & Maize & -0.03 & 0.12 & 0.27 & 0.32 & 0.12 & 0.25 & 0.27 \\
\hline & Sorghum & -0.68 & -0.88 & -1.36 & -1.67 & -0.97 & -1.67 & -2.91 \\
\hline \multirow{4}{*}{$\begin{array}{l}\text { Trans-Gangetic } \\
\text { Plains }\end{array}$} & Rice & -0.37 & -0.40 & -0.54 & -0.69 & -0.44 & -0.72 & -1.30 \\
\hline & Cotton & -0.59 & -0.86 & -1.50 & -1.78 & -0.98 & -1.74 & -2.99 \\
\hline & Pearl Millet & 2.09 & 8.43 & 15.58 & 18.90 & 8.63 & 16.49 & 22.03 \\
\hline & Maize & -0.65 & -0.90 & -1.53 & -1.83 & -1.03 & -1.81 & -3.14 \\
\hline \multirow{2}{*}{$\begin{array}{c}\text { Eastern Plateau } \\
\text { \& Hills }\end{array}$} & Rice & -0.67 & -1.08 & -1.71 & -2.12 & -1.16 & -2.03 & -3.27 \\
\hline & Maize & 0.28 & 0.30 & 0.30 & 0.43 & 0.29 & 0.46 & 0.78 \\
\hline \multirow{3}{*}{$\begin{array}{c}\text { Central Plateau } \\
\& \text { Hills }\end{array}$} & Sorghum & -4.54 & -5.71 & -8.76 & -10.80 & -6.35 & -10.87 & -19.08 \\
\hline & Maize & -1.33 & -1.75 & -2.72 & -3.35 & -1.93 & -3.33 & -5.73 \\
\hline & Groundnut & 0.55 & 0.95 & 1.59 & 1.94 & 1.03 & 1.84 & 2.95 \\
\hline \multirow{3}{*}{$\begin{array}{c}\text { Western Plateau } \\
\text { \& Hills }\end{array}$} & Sorghum & 4.68 & 6.15 & 8.56 & 11.01 & 6.47 & 10.93 & 18.13 \\
\hline & Cotton & -1.74 & -2.24 & -3.36 & -4.19 & -2.45 & -4.19 & -7.18 \\
\hline & Sugarcane & -3.66 & -4.39 & -6.17 & -7.84 & -4.75 & -7.97 & -13.87 \\
\hline \multirow{2}{*}{$\begin{array}{c}\text { Southern Plateau } \\
\& \text { Hills }\end{array}$} & Rice & -0.72 & -1.06 & -1.65 & -2.05 & -1.14 & -1.99 & -3.27 \\
\hline & Groundnut & -1.56 & -1.96 & -3.06 & -3.75 & -2.19 & -3.77 & -6.62 \\
\hline \multirow{3}{*}{$\begin{array}{c}\text { East Coast Plains } \\
\quad \& \text { Hills }\end{array}$} & Rice & -0.37 & -0.57 & -0.93 & -1.13 & -0.62 & -1.09 & -1.79 \\
\hline & Groundnut & -0.49 & -0.52 & -0.74 & -0.93 & -0.58 & -0.97 & -1.79 \\
\hline & Sugarcane & -9.91 & -12.94 & -20.26 & -24.87 & -14.37 & -24.79 & -42.87 \\
\hline \multirow{3}{*}{$\begin{array}{c}\text { West Coast } \\
\text { Plains \& Ghats }\end{array}$} & Rice & 0.01 & 0.07 & 0.14 & 0.16 & 0.07 & 0.14 & 0.21 \\
\hline & Groundnut & -1.51 & -1.82 & -2.75 & -3.39 & -2.02 & -3.44 & -6.10 \\
\hline & Finger Millet & 1.10 & 1.38 & 2.14 & 2.63 & 1.54 & 2.64 & 4.63 \\
\hline \multirow{3}{*}{$\begin{array}{c}\text { Gujarat Plains \& } \\
\text { Hills }\end{array}$} & Pearl Millet & -1.23 & -2.00 & -4.17 & -4.70 & -2.45 & -4.54 & -7.95 \\
\hline & Cotton & 0.02 & -0.30 & -1.06 & -1.08 & -0.44 & -0.95 & -1.58 \\
\hline & Groundnut & -1.26 & -2.31 & -4.97 & -5.58 & -2.82 & -5.31 & -9.11 \\
\hline \multirow{2}{*}{$\begin{array}{l}\text { Western Dry } \\
\text { Region }\end{array}$} & Pearl Millet & -0.84 & -0.82 & -1.17 & -1.45 & -0.95 & -1.56 & -3.01 \\
\hline & Maize & -1.03 & -1.32 & -2.03 & -2.50 & -1.46 & -2.51 & -4.37 \\
\hline
\end{tabular}

Source: Authors estimation.

Note: Direction of rainfall for the future projections was premised on trend analysis for the period, 2001-2011.

period in Trans-Gangetic Plains. On the other hand, for the same period yield will reduce by 4.17 and 1.17 percent in Gujarat Plains \& Hills and Western Dry Region.

\subsubsection{Projected Impact under RCP 8.5}

By the end of the century, maize yield is projected to increase by 12 percent in Western Himalayan Region and Lower Gangetic Plains. Under mid-term period, yield will lower by 3.33 and 2.51 percent in Central Plateau \& Hills and Western Dry Region. In Western and Eastern Hima- layan Region, rice yield is likely to reduce by 5.52 and 6.72 percent by 2050 s, respectively. Rice yield in Lower Gangetic Plains is projected to decline by 4.87 percent by 2080s. Yield loss in case of Pearl millet by 2080s is expected to be around 7 and 3 percent in Gujarat Plains $\&$ Hills Western Dry Region respectively. The maximum decline in cotton yield was observed in Western Plateau $\&$ Hills, where yield is expected to decline by 4.19 and 7.18 percent under mid and long-term period. By 2050s, Finger millet yield will increase by 2.64 percent in West 
Coast Plains \& Ghats. By 2080s, sorghum is projected to decline up to 19 percent in Central Plateau \& Hills. While on the other hand, for the similar period it will increase by about 18 percent in Western Plateau \& Hills. In Middle Gangetic Plains and East Coast Plains \& Hills, sugarcane yield is expected to decline by 21.17 and 24.79 percent under mid-term period, respectively. The yield of ground is projected to decline by 9.91 and 6.62 percent in Gujarat
Plains \& Hills and Southern Plateau \& Hills by 2080s, respectively.

\subsection{Marginal Effect and Projected Change for rabi Crop Yields}

\subsubsection{Marginal Effects}

As shown in Table 4, marginal effect of climate variables

Table 4. Regionally aggregated climate change impacts and projections for $r a b i$ crop yields(percent)

\begin{tabular}{|c|c|c|c|c|c|c|c|c|}
\hline \multirow{5}{*}{$\begin{array}{c}\text { Agro-climatic } \\
\text { Zone }\end{array}$} & \multirow{5}{*}{ Crops } & \multirow{5}{*}{$\begin{array}{c}\text { Marginal } \\
\text { Effects }\end{array}$} & \multicolumn{3}{|c|}{ With RCP 4.5 temperature projections } & \multicolumn{3}{|c|}{ With RCP 8.5 temperature projections } \\
\hline & & & 2030s & $2050 \mathrm{~s}$ & 2080s & 2030s & $2050 \mathrm{~s}$ & 2080s \\
\hline & & & $\Delta \operatorname{MinT}=1.36$ & $\Delta \mathrm{MinT}=2.14$ & $\Delta \operatorname{MinT}=2.63$ & $\Delta \operatorname{MinT}=1.50$ & $\Delta \mathrm{MinT}=2.60$ & $\Delta \mathrm{MinT}=4.43$ \\
\hline & & & $\Delta \mathrm{MaxT}=1.26$ & $\Delta \mathrm{MaxT}=1.81$ & $\Delta \mathrm{MaxT}=2.29$ & $\Delta \mathrm{MaxT}=1.36$ & $\Delta \mathrm{MaxT}=2.30$ & $\Delta \mathrm{MaxT}=3.94$ \\
\hline & & & $\Delta \mathrm{R}=(+/-) 5 \%$ & $\Delta \mathrm{R}=(+/-) 10 \%$ & $\begin{array}{c}\Delta \mathrm{R}=(+/-) \\
12 \%\end{array}$ & $\Delta \mathrm{R}=(+/-) 5 \%$ & $\begin{array}{c}\Delta \mathrm{R}=(+/-) \\
10 \%\end{array}$ & $\begin{array}{c}\Delta \mathrm{R}=(+/-) \\
12 \%\end{array}$ \\
\hline \multirow{2}{*}{$\begin{array}{l}\text { Western Hima- } \\
\text { layan Region }\end{array}$} & Wheat & -0.47 & -0.66 & -1.05 & -1.29 & -0.73 & -1.27 & -2.14 \\
\hline & Barley & -0.76 & -0.91 & -1.25 & -1.60 & -0.98 & -1.63 & -2.81 \\
\hline \multirow{2}{*}{$\begin{array}{l}\text { Eastern Hima- } \\
\text { layan Region }\end{array}$} & Wheat & -2.03 & -2.61 & -3.98 & -4.93 & -2.87 & -4.93 & -8.49 \\
\hline & $\begin{array}{l}\text { Rapeseed \& } \\
\text { Mustard }\end{array}$ & -1.08 & -1.44 & -2.16 & -2.70 & -1.56 & -2.68 & -4.53 \\
\hline \multirow{2}{*}{$\begin{array}{c}\text { Lower Gangetic } \\
\text { Plains }\end{array}$} & Wheat & -0.96 & -1.04 & -1.45 & -1.83 & -1.14 & -1.90 & -3.43 \\
\hline & $\begin{array}{l}\text { Rapeseed \& } \\
\text { Mustard }\end{array}$ & -1.21 & -1.67 & -2.46 & -3.10 & -1.79 & -3.06 & -5.12 \\
\hline \multirow{3}{*}{$\begin{array}{l}\text { Middle Gangetic } \\
\text { Plains }\end{array}$} & Wheat & -0.28 & -0.37 & -0.56 & -0.69 & -0.40 & -0.69 & -1.18 \\
\hline & $\begin{array}{l}\text { Rapeseed \& } \\
\text { Mustard }\end{array}$ & 1.04 & 1.26 & 1.90 & 2.36 & 1.39 & 2.38 & 4.15 \\
\hline & Barley & 0.04 & 0.05 & 0.10 & 0.12 & 0.06 & 0.12 & 0.22 \\
\hline \multirow{3}{*}{$\begin{array}{l}\text { Upper Gangetic } \\
\text { Plains }\end{array}$} & Wheat & -0.09 & -0.11 & -0.17 & -0.21 & -0.12 & -0.21 & -0.37 \\
\hline & Barley & 0.01 & 0.03 & 0.06 & 0.08 & 0.03 & 0.06 & 0.08 \\
\hline & $\begin{array}{l}\text { Rapeseed \& } \\
\text { Mustard }\end{array}$ & 0.20 & 0.29 & 0.46 & 0.57 & 0.32 & 0.56 & 0.91 \\
\hline \multirow{3}{*}{$\begin{array}{l}\text { Trans-Gangetic } \\
\text { Plains }\end{array}$} & Wheat & -1.02 & -1.53 & -2.57 & -3.11 & -1.70 & -3.01 & -5.02 \\
\hline & Barley & -0.26 & -0.30 & -0.40 & -0.52 & -0.32 & -0.54 & -0.95 \\
\hline & $\begin{array}{l}\text { Rapeseed \& } \\
\text { Mustard }\end{array}$ & 1.59 & 2.32 & 3.89 & 4.70 & 2.59 & 4.58 & 7.71 \\
\hline \multirow{2}{*}{$\begin{array}{c}\text { Eastern Plateau } \\
\text { \& Hills }\end{array}$} & Wheat & -0.26 & -0.30 & -0.48 & -0.58 & -0.34 & -0.59 & -1.07 \\
\hline & Linseed & -0.87 & -1.23 & -2.00 & -2.43 & -1.36 & -2.39 & -4.04 \\
\hline \multirow{2}{*}{$\begin{array}{c}\text { Central Plateau } \\
\text { \& Hills }\end{array}$} & Wheat & -0.94 & -1.31 & -2.07 & -2.54 & -1.44 & -2.50 & -4.22 \\
\hline & $\begin{array}{l}\text { Rapeseed \& } \\
\text { Mustard }\end{array}$ & 2.73 & 3.69 & 5.76 & 7.10 & 4.06 & 7.03 & 11.97 \\
\hline \multirow[b]{2}{*}{$\begin{array}{c}\text { Western Plateau } \\
\text { \& Hills }\end{array}$} & Wheat & -0.88 & -1.12 & -1.62 & -2.05 & -1.21 & -2.05 & -3.49 \\
\hline & $\begin{array}{l}\text { Rapeseed \& } \\
\text { Mustard }\end{array}$ & -1.86 & -2.05 & -2.45 & -3.29 & -2.13 & -3.44 & -6.01 \\
\hline \multirow{2}{*}{$\begin{array}{c}\text { Southern Plateau } \\
\text { \& Hills }\end{array}$} & Wheat & -1.27 & -1.73 & -2.62 & -3.27 & -1.88 & -3.23 & -5.44 \\
\hline & Linseed & -1.35 & -1.72 & -2.51 & -3.16 & -1.86 & -3.16 & -4.88 \\
\hline \multirow{2}{*}{$\begin{array}{c}\text { East Coast Plains } \\
\& \text { Hills }\end{array}$} & Wheat & -1.46 & -2.01 & -3.19 & -3.92 & -2.22 & -3.86 & -6.56 \\
\hline & $\begin{array}{l}\text { Rapeseed \& } \\
\text { Mustard }\end{array}$ & 3.45 & 4.71 & 7.41 & 9.10 & 5.19 & 8.99 & 15.31 \\
\hline \multirow{2}{*}{$\begin{array}{c}\text { West Coast Plains } \\
\text { \& Ghats }\end{array}$} & Wheat & 0.33 & 0.48 & 0.77 & 0.95 & 0.54 & 0.92 & 1.54 \\
\hline & $\begin{array}{l}\text { Rapeseed\& Mus- } \\
\text { tard }\end{array}$ & 2.45 & 3.37 & 6.34 & 6.53 & 3.71 & 7.47 & 10.91 \\
\hline \multirow[b]{2}{*}{$\begin{array}{l}\text { Gujarat Plains \& } \\
\text { Hills }\end{array}$} & Wheat & 0.44 & 1.29 & 3.20 & 3.49 & 1.62 & 3.20 & 5.29 \\
\hline & $\begin{array}{l}\text { Rapeseed \& } \\
\text { Mustard }\end{array}$ & 0.31 & 0.86 & 2.13 & 2.32 & 1.09 & 2.14 & 3.56 \\
\hline \multirow{2}{*}{$\begin{array}{l}\text { Western Dry } \\
\text { Region }\end{array}$} & Wheat & -2.73 & -3.71 & -5.84 & -7.17 & -4.09 & -7.03 & -12.05 \\
\hline & $\begin{array}{l}\text { Rapeseed \& } \\
\text { Mustard }\end{array}$ & 2.57 & 3.50 & 5.50 & 6.75 & 3.86 & 6.69 & 11.42 \\
\hline
\end{tabular}

Source: Authors estimation

Note: Direction of rainfall for the future projections was premised on trend analysis for the period, 2001-2011. 
on wheat yield was found to be negative in all the growing regions except West Coast Plains \& Ghats and Gujarat Plains \& Hills. The maximum reduction in wheat yield was observed in Western Dry Region (2.73 percent) and Eastern Himalayan Region (2.03 percent). On the other hand,yield of barley showed a decline of 0.76 and 0.26 percent in Western Himalayan Region and Trans-Gangetic Plains, whereas in Middle and Upper Gangetic Plains, it registered a marginal increase of 0.04 and 0.01 percent. In nearly all the growing regions, rapeseed \& mustard was positively impacted reflecting high tolerance and resilience of crop to the changing climatic conditions. In East Coast Plains \& Hills, Central Plateau \& Hills and Western Dry Region, rapeseed \& mustard yield showed the maximum increase of 3.45, 2.73 and 2.57 percent respectively. On the other spectrum, yield reduced by 1.86 and 1.21 percent in Western Plateau \& Hills and Lower Gangetic Plains. During the period, linseed yield declined by 1.35 and 0.87 percent in both the Eastern and Southern Plateau \& Hills respectively.

\subsubsection{Projected Impact under RCP 4.5}

Climate projections for rabi crops indicate that by $2050 \mathrm{~s}$ and 2080s wheat yield will reduce by 5.84 and 7.17 percent in Western Dry Region. For the similar periods it will reduce by 3.98 and 4.93 percent in Eastern Himalayan Region and 2.57 and 3.11 percent in Trans-Gangetic Plains. In Gujarat Plains \& Hills, wheat yield is likely to increase by 3.20 percent by 2050 s. Rapeseed $\&$ mustard is projected to increase up to 9.10, 7.10 and 6.75, percent by 2080s in East Coast Plains \& Hills, Central Plateau \& Hills and Western Dry Region. By 2050s, barley yield will reduce by 1.25 and 0.4 percent in Western Himalayan Region and Trans-Gangetic Plains.

\subsubsection{Projected Impact under RCP 8.5}

By $2080 \mathrm{~s}$, wheat yield is projected to decline by 12.05 , 8.49 and 6.56 percent in Western Dry Region, Eastern Himalayan Region and East Coast Plains \& Hills, respectively. InTrans-GangeticPlains wheat yield will be lower by 3.01 percent under the mid-term period. Barley was not much impacted to climate change, as yield loss were projected to be 0.54 and 1.63 percent by 2050 s, in Trans-Gangetic Plains and Western Himalayan Region. For the long-term period, rapeseed \& Mustard yield is expected to increase by around 11-12 percent in Central Plateau \& Hills, West Coast Plains \& Ghats and Western Dry Region. In Eastern Plateau \& Hills and Southern Plateau \& Hills, linseed yield is expected to decline by 2.39 and 3.16 percent by $2050 \mathrm{~s}$.

\section{Conclusion}

The study made an attempt to examine the large-scale heterogeneity across the Indian landscape by capturing the idiosyncrasy of ACZs and understanding the sensitivity of major kharif and rabi crop yields to climate change at a spatially disaggregated level. An examination of spatio-temporal change in temperature revealed a rise in both the annual mean maximum and minimum temperature, with more pronounced changesobserved in annual mean minimum temperature across the ACZs. The empirical results indicate progressive reduction in most of the crop yields, but the magnitude impacts and projections vary by ACZs. The changes in crop yields projected under RCP 8.5 were more pronounced compared to RCP 4.5; largely due to higher temperature projections under the former.The results indicate that the direct and nearterm impact of climate change on crop yields will be smaller as compared to mid and long-term projections. Thus the study suggests that there is a dire need to formulate region-specific interventions and adaptation strategies to maintain food security and livelihood protection of farmersin the respective region. Concerted efforts are needed in development and dissemination of climate resilient varieties and on-farm management practices, promotion of integrated watershed management which includes up-scaling techniques such as solar pumps, drip irrigation and sprinklers for greater water use efficiency. Improved awareness, communication andtraining regarding micro-level sensitivity to climate induced perturbations in conjunction with insurance covers across regionsis crucial for desired changes in farming practices. As climate becomes more unpredictable, opportunities for diversification to non-farm activities becomes essential for reducing exposure to livelihood shocks. From policy perspective, mainstreaming climate adaptation in the rural developmental paradigm is imperative to improve the envisaged agriculture outputs and outcomes. The long-term essentiality for regional planning arises from the need for a framework that would act as a stabilizer, addressing regional imbalances and ensuring intergenerational equity in resource use.

Our main interest through this study was to understand the spatial distribution of climate impact on crop yields. However, the results of this study needs to be interpreted with caution because of certain limitations. First, the sensitivity of crop yields to changes in climate variables was examined, assuming linear climate-crop yield relation which might not be true under certain conditions. Moreover, such an assumption ignores the incremental impact of climate parameters on crop yields. 
There are studies that show non-linearity between climate variables and crop yields ${ }^{[53,24]}$. Second, due to unavailability of future climate estimates at agro-climatic zone level, our projections assume uniform changes in rainfall and temperature across the zones. However, climate variations differ across regions, and thus may influence the nature of climate change projections on crop yields.

\section{References}

[1] IPCC. Summary for Policymakers. In: Global Warming of $1.5^{\circ} \mathrm{C}$. Masson-Delmotte, V., P. Zhai, H.-O. Pörtner, D. Roberts, J. Skea, P.R. Shukla, A. Pirani, W. Moufouma-Okia, C. Péan, R. Pidcock, S. Connors, J.B.R. Matthews, Y. Chen, X. Zhou, M.I. Gomis, E. Lonnoy, T. Maycock, M. Tignor, \& T. Waterfield (Eds.)], World Meteorological Organization, Geneva, Switzerland, 2018.

[2] Lobell, D.B., Field, C.B. Global scale climate-crop yield relationships and the impacts of recent warming. Environmental Research Letters, 2007, 2(1): 014002 .

[3] Nelson, G.C., Rosegrant, M.W., Koo, J., Robertson, R., Sulser, T., Zhu, T., Ringler, C., Msangi, S., Palazzo, A., Batka, M., \&Magalhaes, M. Climate change: impact on agriculture and costs of adaptation. International Food Policy Research Institute, Washington, DC, 2009.

[4] Lobell, D.B., Schlenker, W., Costa-Roberts, J. Climate trends and global crop production since 1980. Science, 2011, 333(6042): 616-620.

[5] Mishra, A., Singh, R., Raghuwanshi, N.S., Chatterjee, C., Froebrich, J. Spatial variability of climate change impacts on yield of rice and wheat in the Indian Ganga Basin. Science of the Total Environment, 2013, 468: 132-138.

[6] Mall, R.K., Singh, R., Gupta, A., Srinivasan, G., Rathore, L.S. Impact of climate change on Indian agriculture: A review. Climatic Change, 2006, 78(24): 445-478.

[7] Aggarwal, P.K. Global climate change and Indian agriculture: impacts, adaptation and mitigation. Indian Journal of Agricultural Sciences, 2008, 78(11): 911-919.

[8] Falkenmark, M., Rockström, J., Karlberg, L. Present and future water requirements for feeding humanity. Food security, 2009, 1(1): 59-69.

[9] Nelson, G. C., Rosegrant, M. W., Palazzo, A., Gray, I., Ingersoll, C., Robertson, R., Tokgoz, S., Zhu, T., Sulser, T., Ringler, C. Food Security, Farming and Climate Change to 2050. Research Monograph,
International Food Policy Research Institute, Washington, DC, 2010.

[10] Singh, P., Singh, N., Nedumaran, S., Bantilan, C., Byjesh, K. Evaluating adaptation options at crop level for climate change in the tropics of south Asia and west Africa. In: Climate Change Challenges and Adaptations at Farm-level: Case Studies from Asia and Africa, Eds: N. P. Singh, C. Bantilan, K. Byjesh, and S. Nedumaran. CABI Private Limited, 2015, 115-137.

[11] FAO, 2016.

[12] Gornall, J., Betts, R., Burke, E., Clark, R., Camp, J., Willett, K., Wiltshire, A. Implications of climate change for agricultural productivity in the early twenty-first century. Philosophical Transactions of the Royal Society B: Biological Sciences, 2010, 365(1554): 2973-2989.

[13] Porter, J.R. et al. Food security and food production systems. In: Climate change 2014: impacts, adaptation, and vulnerability. Part A: global and sectoral aspects (C.B. Field, V.R. Barros, D.J.

[14] Kothawale, D.R., Rupa Kumar, K. On the recent changes in surface temperature trends over India. Geophysical Research Letters, 2005, 32(18).

[15] Kothawale, D.R., Munot, A.A., Kumar, K.K. Surface air temperature variability over India during 1901-2007, and its association with ENSO. Climate Research, 2010, 42(2): 89-104.

[16] Rao, B.B., Chowdary, P.S., Sandeep, V.M., Rao, V.U.M., Venkateswarlu, B. Rising minimum temperature trends over India in recent decades: implications for agricultural production. Global and Planetary Change, 2014, 117: 1-8.

[17] Mondal, A., Khare, D., Kundu, S. Spatial and temporal analysis of rainfall and temperature trend of India. Theoretical and applied climatology, 2015, 122(1-2): 143-158.

[18] Kumar, V., Jain, S.K., Singh, Y. Analysis of longterm rainfall trends in India. Hydrological Sciences Journal-Journal des Sciences Hydrologiques, 2010, 55(4): 484-496.

[19] Jayaraman, T., Murari, K. Climate change and agriculture: Current and future trends, and implications for India. Review of Agrarian Studies, 2014, 4(1): $1-49$.

[20] Goswami, B.N., Venugopal, V., Sengupta, D., Madhusoodanan, M.S., Xavier, P.K., Increasing trend of extreme rain events over India in a warming environment. Science, 2006 314(5804): 1442-1445.

[21] Jain, S.K., Kumar, V. Trend analysis of rainfall and temperature data for India. Current Science, 2012, 37-49. 
[22] Acharya, S.S. Sustainable agriculture and rural livelihoods. Agricultural Economics Research Review, 2006, 19(2): 205-217.

[23] Jain, M., Naeem, S., Orlove, B., Modi, V., DeFries, R.S. Understanding the causes and consequences of differential decision-making in adaptation research: adapting to a delayed monsoon onset in Gujarat, India. Global Environmental Change, 2015, 31: 98109.

[24] Guiteras R. The impact of climate change on Indian agriculture. Manuscript, Department of Economics, University of Maryland, College Park, Maryland, 2009.

[25] Kumar, S.N., Aggarwal, P.K., Rani, D.S., Saxena, R., Chauhan, N., Jain, S. Vulnerability of wheat production to climate change in India. Climate Research, 2014, 59(3): 173-187.

[26] Birthal, P.S., Khan, T.M., Negi, D.S., Agarwal, S. Impact of climate change on yields of major food crops in India: implications for food security. Agricultural Economics Research Review, 2014a, 27 (347-2016-17126): 145-155.

[27] Cline, W. Global Warming and Agriculture: Impact Estimates by Country, Washington, DC, 2007.

[28] Mall, R.K., Singh, R., Gupta, A., Srinivasan, G., Rathore, L.S. Impact of climate change on Indian agriculture: a review. Climatic change, 2006, 78(24): 445-478.

[29] Aggarwal, P.K. Vulnerability of Indian agriculture to climate change: current state of knowledge, paper presented at the National Workshop - Review of Implementation of Work Programme towards Indian Network of Climate Change Assessment, Ministry of Environment and Forests, New Delhi, 2009,

[30] Singh, N.P., Bantilan, C., Byjesh, K. Vulnerability and policy relevance to drought in the semi-arid tropics of Asia-A retrospective analysis. Weather and Climate extremes, 2014, 3: 54-61.

[31] Singh, N.P., Anand, B., Singh, S., Khan, A. Mainstreaming climate adaptation in Indian rural developmental agenda: A micro-macro convergence. Climate Risk Management, 2019, 24: 30-41.

[32] Government of India. Agro-climatic regional planning: an overview, Planning Commission, New Delhi, 1989.

[33] Basu, D.N., Guha, G.S. Agro-climatic Regional Planning in India, 1996.

[34] Singh, R.K., Singh, D.N. An agroclimatic approach to agricultural development in India. In: Systems approaches for agricultural development, Eds: de VriesF.P., Teng P., Metselaar K. Springer, Dordrecht. 1993: 111-125.
[35] Chand, M., Puri, V.K. Regional planning in India (Vol.1). Allied Publishers, 1983.

[36] Rosenzweig, C., Parry, M.L. Potential impact of climate change on world food supply. Nature, 1994, 367(6459): 133-138.

[37] Rao, D.G., Sinha,S.K. Impact of Climate Change on Simulated Wheat Production in India.In: Implications of Climate Change for International Agriculture: Crop Modelling Study (Rosenzweig C, Iglesias A eds), US Environmental Protection Agency, Washington, 1994.

[38] Lal, M., K.K. Singh, L.S. Rathore, G. Srinivasan and S.A. Saseendran. Vulnerability of Rice and Wheat Yields in North-West India to Future Changes in Climate. Agriculture and Forest Meteorology, 1998, 89: 101-114.

[39] Mathauda, S.S., H.S. Mavi, B.S. Bhangoo, B.K. Dhaliwal. Impact of Projected Climate Change on Rice Production in Punjab (India). Tropical Ecology, 2000, 41(1): 95-98.

[40] Deschênes, O., Greenstone, M. The economic impacts of climate change: evidence from agricultural output and random fluctuations in weather. American Economic Review, 2007, 97(1): 354-385.

[41] Mendelsohn, R., Nordhaus, W., Shaw, D. The impact of global warming on agriculture: a Ricardian analysis. American Economic Review, 1994, 84: 753-771.

[42] Kelly, D.L., Kolstad, C.D., Mitchell, G.T. Adjustment costs from environmental change. Journal of Environmental Economics and Management, 2005, 50(3): 468-495.

[43] Birthal, P.S., Negi, D.S., Kumar, S., Aggarwal, S., Suresh, A., Khan, M. How sensitive is Indian agriculture to climate change? Indian Journal of Agricultural Economics, 2014b, 69(902-2016-68357): 474-487.

[44] Kala, N., Kurukulasuriya, P., Mendelsohn, R. The impact of climate change on agro-ecological zones: evidence from Africa. Environment and Development Economics, 2012, 17(6): 663-687.

[45] Wooldridge, J. M. Econometric Analysis of Cross Section and Panel Data. Cambridge, MA: MIT Press, 2002.

[46] Greene, W. Econometric Analysis. Upper Saddle River, NJ: Prentice-Hall, 2000.

[47] Banerjee, A. Panel Data Unit Roots and Cointegration: An Overview, Oxford Bulletin of Economics and Statistics, 1999, Special Issue 035-9049.

[48] Nelson, M., Donggyu S. A. Computationally Simple Cointegration Vector Estimator for Panel Data, Department of Economics working Papers, The Ohio 
State University, 2001.

[49] Kmenta, J. Elements of Econometrics. 2nd ed. New York: Macmillan, 1986.

[50] Beck, N., Katz, J.N. What to do (and not to do) with time-series cross-section data. American political science review, 1995, 89(3): 634-647.

[51] Hoechle, D. Robust standard errors for panel regressions with cross-sectional dependence. The Stata journal, 2007, 7(3): 281-312.
[52] Ministry of Earth Sciences (MoES). Climate Change over India: An Interim Report, Eds. Krishnan R., and Sanjay J. ESSO-Indian Institute of Tropical Meteorology, Ministry of Earth Sciences, Government of India, Pune, 2017.

[53] Schlenker, W., Roberts, M. Nonlinear effects of weather on crop yields: implications for climate change. Review of Agricultural Economics, 2006, 28. 